\title{
Effects of Adjuvants on Safety and Efficacy of an Escherichia coli J5 Bacterin*
}

\author{
J. S. Hogan, ${ }^{1}$ V. B. Cannon, ${ }^{1}$ K. L. Smith, ${ }^{1}$ C. Rinehart, ${ }^{2}$ and S. Miller ${ }^{2}$ \\ ${ }^{1}$ Department of Animal Sciences, The Ohio State University \\ Ohio Agricultural Research and Development Center, Wooster 44691 \\ ${ }^{2}$ Boehringer Ingelheim Vetmedica, Inc., St. Joseph, MO 64506
}

\section{ABSTRACT}

The effects of using a water-soluble adjuvant or an emulsified oil-based adjuvant on the safety, antibody titer, and clinical responses of an Escherichia coli J5 bacterin were tested in an experimental infection trial. Fifty-one cows were assigned to 17 blocks of 3 . Two cows within each block of 3 were vaccinated with a commercially prepared $E$. coli J5 bacterin containing either a water-soluble adjuvant or the same bacterin preparation emulsified in oil. One cow in each block was an unvaccinated control. Cows were immunized at drying off and $42 \mathrm{~d}$ later. The right or left front mammary quarter of each experimental cow was challenged by intramammary infusion of $E$. coli 727 between 14 and 35 DIM. Areas of inflammation at the primary injection site were greater 1,2 , and $3 \mathrm{~d}$ following primary vaccination for bacterin containing oil-in-water adjuvant compared with bacterin containing water-soluble adjuvant. Whey anti-E. coli J5 IgG titers were higher at calving for cows vaccinated with bacterin containing oil-in-water adjuvant than for cows either vaccinated with bacterin containing water-soluble adjuvant or unvaccinated controls. Serum x-E. coli J5 IgG titers were higher at calving for vaccinated cows than for unvaccinated controls. Peak bacterial counts in milk from challenged quarters were greater for unvaccinated controls than for cows vaccinated with bacterin containing water-in-oil adjuvant. Bacterial counts in milk from challenged quarters and clinical score both were greater in unvaccinated controls than cows vaccinated with bacterin containing water-in-oil adjuvant between 12 and $24 \mathrm{~h}$ postchallenge. Clinical responses were similar between unvaccinated controls and cows vaccinated with bacterin containing water-soluble adjuvant.

(Key words: adjuvant, vaccine, mastitis)

Received August 31, 2004

Accepted November 11, 2004.

Corresponding author: J. S. Hogan; e-mail: hogan.4@osu.edu.

*Salaries and research support were provided by state and federal funds appropriated to the Ohio Agricultural Research and Development Center, The Ohio State University. Manuscript No. 29-04AS.

\section{INTRODUCTION}

The use of Escherichia coli J5 bacterins to enhance resistance against IMI caused by gram-negative bacteria during the periparturient period and early lactation was initially reported by Gonzales et al. (1983) 2 decades ago. Field trials and experimental infection trials have subsequently shown that the use of $E$. coli J5 bacterins often reduced the severity and duration of clinical mastitis (Hogan et al., 1992a,b). However, the use of $E$. coli J5 bacterins in experimental challenge trials has yielded little protection against IMI or clinical disease in subsequent reports (Tomita et al., 2000; Takemura et al., 2002). Attempts to enhance protection provided by $E$. coli $\mathrm{J} 5$ bacterins by local immunization were unsuccessful (Tomita et al., 1998; Smith et al., 1999). Burton et al. (2002) recently reported that multiple systemic immunizations elevated antibody titers and allowed isotype switching compared with a primary and 2 booster immunizations commonly used in previous experiments. Potentially problematic to the use of multiple systemic immunizations is the fact that injection site inflammatory reactions can occur with bacterins containing adjuvant (Spickler and Roth, 2003).

Adjuvants are substances used in combination with a specific antigen that produce more immunity than the antigen alone (Ramon, 1924). Oil-in-water adjuvants are generally unsurpassed in efficacy, but can result in abscesses and lesions at the site of injection (Dalsgaard, 1987). Oil-in-water adjuvants were used in E. coli J5 bacterins previously shown to be efficacious (Gonzales et al., 1983; Hogan et al., 1992a,b). The purpose of the current trial was to evaluate safety, antibody titer responses, and efficacy of a commercially prepared $E$. coli J5 bacterin with an oil-in-water emulsion adjuvant or a water-soluble adjuvant.

\section{MATERIALS AND METHODS}

\section{Experimental Cows}

Fifty-one cows in the Ohio Agricultural Research and Development Center dairy herd were assigned to 17 blocks of 3 . Two cows within each block of 3 were vacci- 
nated with a commercially prepared $E$. coli J5 bacterin (Boehringer Ingelheim Vetmedica, Inc., St. Joseph, MO) containing either a water-soluble adjuvant or adjuvant emulsified with a proprietary oil. One cow in each block was an unvaccinated control. Vaccines were provided to and administered by the investigators in a blinded manner. Treatments were masked to individuals evaluating subjective safety and clinical scores. The treatment codes were not broken until data collection and analyses were completed. Cows were immunized at drying off and $42 \mathrm{~d}$ later. Cows within a block were immunized on the same days. Immunizations $(2 \mathrm{~mL})$ were subcutaneous on the upper part of the rib cage just posterior to the scapula. All cows were dried off by abrupt cessation of milking and all 4 quarters were dry treated $60 \mathrm{~d}$ before anticipated calving. Experimental cows were housed and managed similarly.

Four cows immunized with bacterin containing water-soluble adjuvant and 2 unvaccinated controls were excluded from the trial before intramammary challenge for health reasons unrelated to experimental treatment. Data from those cows were omitted from all analyses.

\section{Injection Site and Febrile Response to Immunizations}

Rectal temperatures of vaccinated and unvaccinated control cows within a block were measured immediately before vaccination, $4 \mathrm{~h}$ after immunization, and daily for $4 \mathrm{~d}$ after vaccination. Rectal temperatures were measured with a GLA M525 electronic self-calibrating thermometer (GLA Agricultural Electronics, San Luis Obispo, CA). Vaccinated cows were examined for injection site reactions the day before vaccination, and 1,2 , 3 , and $4 \mathrm{~d}$ after immunization. Length and width of area swollen at injection sites were recorded.

\section{Antibody Titers}

An ELISA was used to determine antibody titer in serum and mammary secretions to $E$. coli J5 in vaccinated and unvaccinated controls. Serum samples were collected from each cow in a block immediately before primary immunization, immediately before the booster, within $12 \mathrm{~h}$ after parturition, immediately before intramammary challenge, and $7 \mathrm{~d}$ after challenge. Whey from mammary secretions was tested at each sampling period as serum, except mammary secretions were not collected $42 \mathrm{~d}$ into the dry period. The ELISA procedures were essentially those detailed by Tyler et al. (1990). Escherichia coli J5 were incubated for $18 \mathrm{~h}$ at $37^{\circ} \mathrm{C}$. Heat-killed bacteria were coated onto microtiter wells by incubation overnight at $37^{\circ} \mathrm{C}$. Isotypes were determined by rabbit antibovine IgG (Sigma Chemical Co., St. Louis, MO) and goat antibovine IgM (Kirkegaard and Perry Laboratories, Gaithersburg, MD). Titer data were expressed as the reciprocal of the dilution $\log _{2}$.

\section{Intramammary Bacterial Challenge}

Escherichia coli 727, originally isolated from a naturally occurring IMI, was used as the intramammary challenge strain. Challenge inoculum was prepared by inoculation of a frozen stock culture of $E$. coli 727 onto blood-esculin agar at $37^{\circ} \mathrm{C}$ for $24 \mathrm{~h}$. A single colony was transferred into trypticase soy broth (BBL Microbiology Systems, Becton Dickinson Co., Cockeysville, MD) and incubated at $37^{\circ} \mathrm{C}$ for $12 \mathrm{~h}$. The stationary phase broth culture was centrifuged, the pellet was resuspended in $10 \mathrm{~mL}$ of PBS, and optical density was adjusted to $70 \%$ transmission at $540 \mathrm{~nm}$. Seven additional 10-fold serial dilutions in PBS were made, and colony-forming units per milliliter were determined by plating $1 \mathrm{~mL}$ in duplicate in MacConkey agar (BBL Microbiology Systems) pour plates. The right or left front mammary quarter of each experimental cow was challenged by intramammary infusion of $E$. coli 727 . The geometric mean of the colony-forming units for challenge inoculum was 72 (range 65 to $77 \mathrm{cfu}$ ) suspended in $1 \mathrm{~mL}$ of PBS. Cows were challenged between 14 and 35 DIM. Cows within a block were challenged on the same day. Infusions were $3 \mathrm{~h}$ after morning milking, and only uninfected quarters were infused.

\section{Quarter Foremilk Samples}

Incidence of naturally occurring IMI at drying off and calving was determined by quarter foremilk samples as previously described (National Mastitis Council, 1999). Quarter foremilk samples were collected 7, 5, and $3 \mathrm{~d}$ before bacterial challenge, immediately before challenge, 3, 6, 9, 12 15, 18, 21, and $24 \mathrm{~h}$ postchallenge, and 2, 3, 4, and $7 \mathrm{~d}$ after challenge. Sample collection and microbiological procedures were as previously described (Todhunter et al., 1991). All gram-negative isolates were identified by motility, lactose fermentation, citrate use, and triple-sugar-iron reaction (National Mastitis Council, 1999).

The colony-forming units per milliliter and SCC were determined in quarter foremilk samples during the postchallenge period. Colony-forming units were determined by appropriate 10 -fold dilutions of sample in PBS. The initial inocula were duplicate $1-\mathrm{mL}$ pour plates of undiluted milk in MacConkey agar. Dilutions were plated on the surface of MacConkey agar plates. All dilutions were in duplicate. Somatic cell count was 
determined by Bentley Somatocount 150 milk somatic cell counter (Bentley Instruments, Inc., Chaska, MN). Samples from clinical quarters were diluted 1:10 and 1:50 (milk:PBS, vol/vol) for counting. Data were expressed as $\log _{10}$ colony-forming units per milliliter of milk and $\log _{10}$ SCC per milliliter of milk.

An IMI was diagnosed when bacteria were isolated from 2 consecutive samples. Duration of IMI was the hours between first and last isolation of bacteria from a quarter. Clinical score of all quarters was recorded at the time quarter foremilk samples were obtained. Clinical score was recorded on a 5 -point scale: $1=$ normal milk and normal quarter, $2=$ normal quarter but questionable milk, $3=$ normal quarter but abnormal milk, $4=$ a swollen quarter and abnormal milk, and $5=$ swollen quarter, abnormal milk, and systemic signs of infection. Rectal temperatures were measured immediately before challenge and at each time that quarter foremilk samples were collected postchallenge.

\section{Statistical Analyses}

Treatment differences among areas of inflammation at injection sites, bacterial counts, rectal temperatures, SCC, and clinical scores were tested by least squares ANOVA (SAS Institute, 1999). Models included treatment, block, time of sampling, and second-order interaction between main effects. Differences between peak bacterial counts and rectal temperatures following challenge in cows having injection site reactions resulting in an area of inflammation greater than $1 \mathrm{~cm}^{2}$ or less than $1 \mathrm{~cm}^{2}$ were tested within experimental groups by least squares ANOVA.

\section{RESULTS}

\section{Injection Site and Febrile Response to Immunizations}

Area of inflammation at the primary injection sites were greater $1,2,3$, and $4 \mathrm{~d}$ following primary vaccination for cows receiving bacterin containing oil-in-water adjuvant compared with bacterin containing water-soluble adjuvant $(P<0.05$; Figure 1$)$. Area of inflammation did not differ between vaccinated treatment groups following booster immunizations $42 \mathrm{~d}$ after drying off ( $P$ $>0.05$ ). Rectal temperatures did not differ among the treatment groups following either primary or booster immunization $(P>0.05$; data not presented).

\section{Antibody Titers}

Serum x-E. coli J5 IgG titers were higher at calving for vaccinated cows than for unvaccinated controls $(P$ $<0.05$; Figure 2). Whey x-E. coli J5 IgG titers (mean \pm
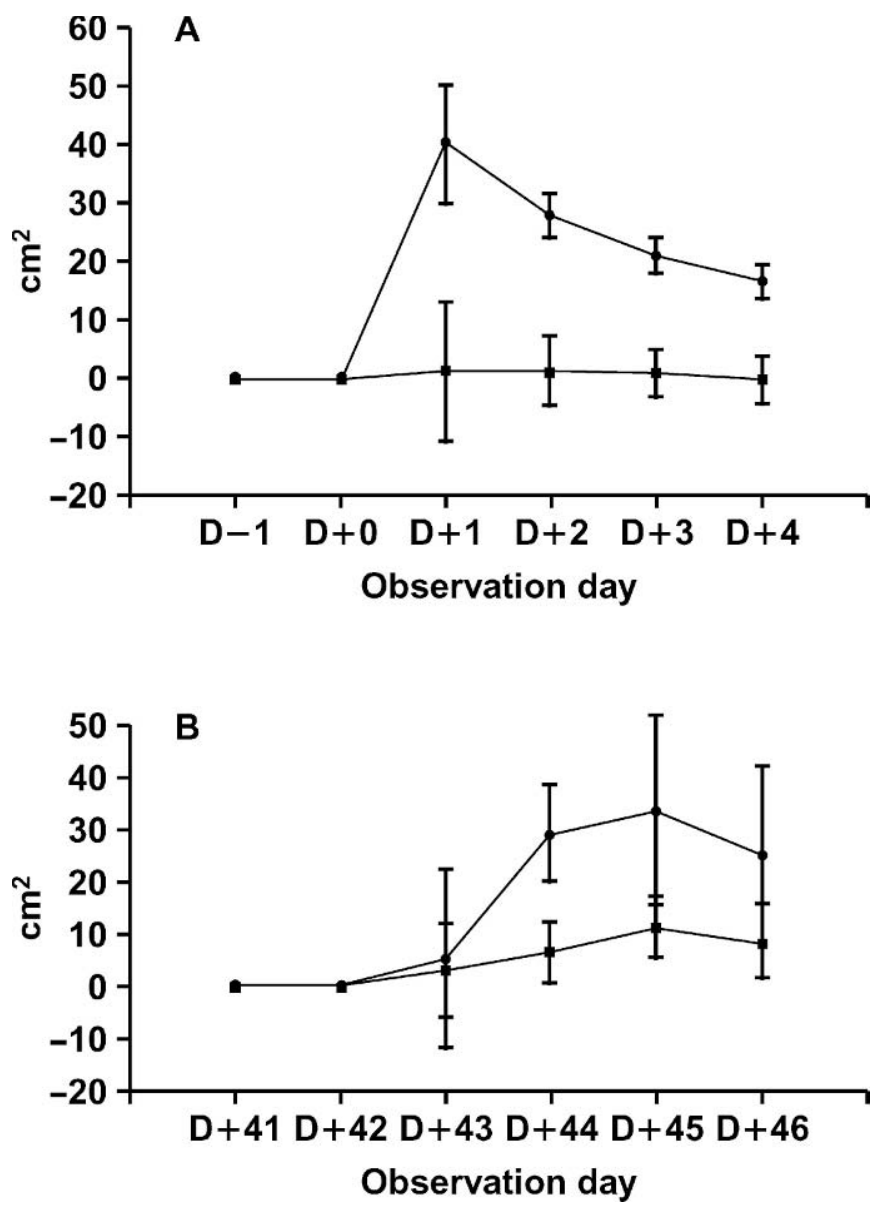

Figure 1. Mean area of inflammation at the primary immunization site (A) and following booster immunization (B) in cows vaccinated with Escherichia coli J5 bacterins containing either oil-in-water adju$\operatorname{vant}(\mathrm{n}=17 ; 0)$ or water soluble adjuvant $(\mathrm{n}=13$; $\mathbf{\square})$. Primary immunizations were at drying off $(\mathrm{D}+0)$ and $42 \mathrm{~d}$ later $(\mathrm{D}+42)$. Dispersion bars represent standard errors of the mean.

$\mathrm{SE})$ in colostrum were higher $(P<0.05)$ for cows vaccinated with bacterin containing oil-in-water adjuvant $\left(13.4 \pm 0.1 \log _{2}\right)$ than cows vaccinated with bacterin containing water-soluble adjuvant $\left(12.5 \pm 0.2 \log _{2}\right)$ or unvaccinated controls $\left(12.7 \pm 0.2 \log _{2}\right)$. Serum and whey $\mathrm{x}-E$. coli J5 IgG titers did not differ among treatment groups either at challenge or postchallenge. Serum and whey $\mathrm{x}-E$. coli J5 IgM titers were similar among treatment groups at each sampling period $(P>0.05)$.

\section{Clinical Response}

The incidences of clinical mastitis did not differ among cows vaccinated with bacterin containing watersoluble adjuvant, cows vaccinated with bacterin containing water-in-oil adjuvant, and unvaccinated controls following intramammary challenge with $E$. coli 727. However, the severity of clinical response differed 

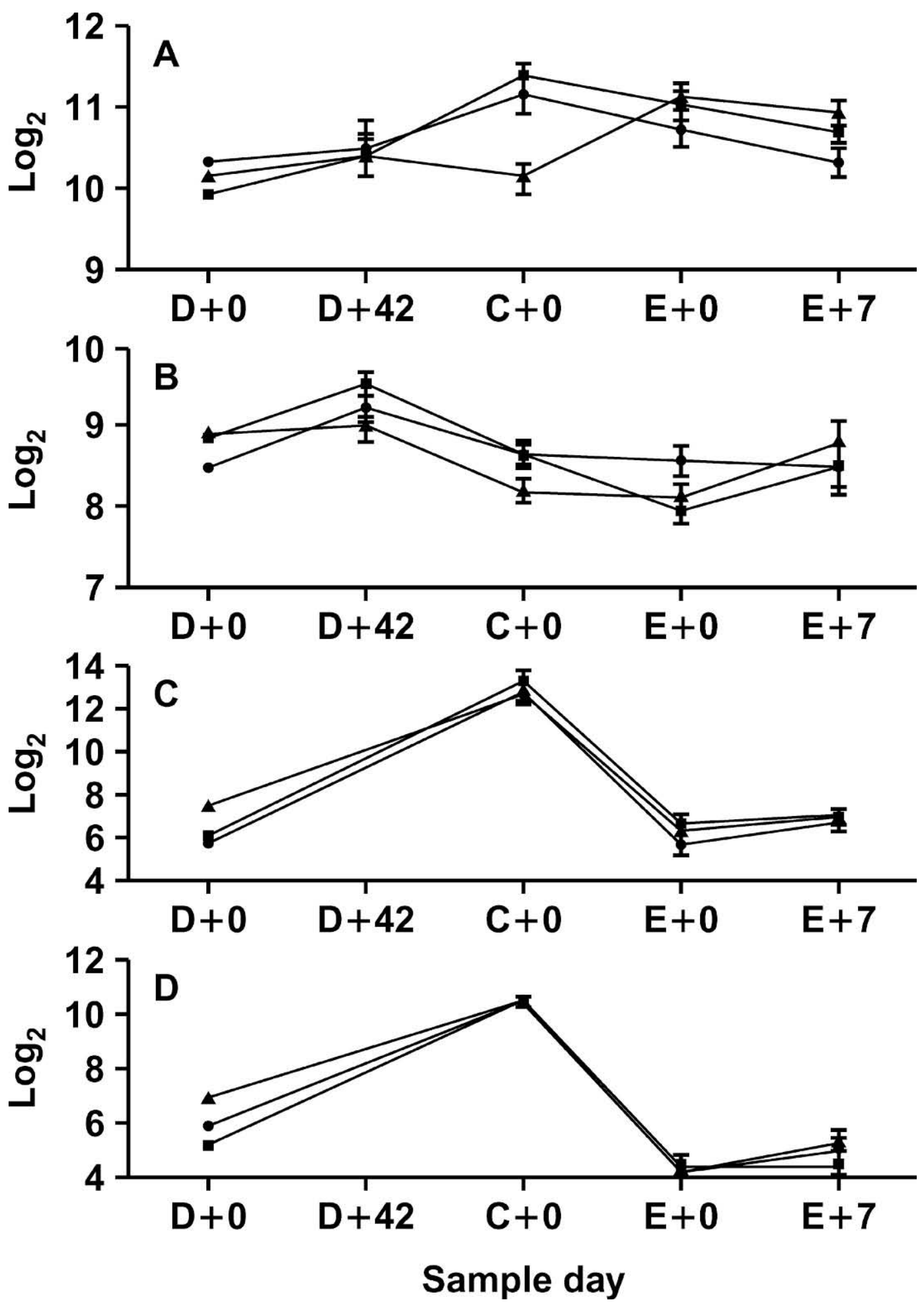

Figure 2. Mean antibody titers for IgG in serum (A), IgM in serum (B), IgG in whey (C), and IgM in whey (D) against Escherichia coli 727 for cows vaccinated with Escherichia coli J5 bacterins containing either oil in water adjuvant $(\mathrm{n}=17$; $\mathbf{\square})$, water soluble adjuvant ( $\mathrm{n}=$ 13 ; $)$, or unvaccinated controls $(n=15 ; \boldsymbol{\Delta})$. Samples were collected at drying off $(D+0)$, calving $(C+0)$, at the time of intramammary challenge $(\mathrm{E}+0)$, and $7 \mathrm{~d}$ after challenge $(\mathrm{E}+7)$. Dispersion bars represent standard errors of the mean. 

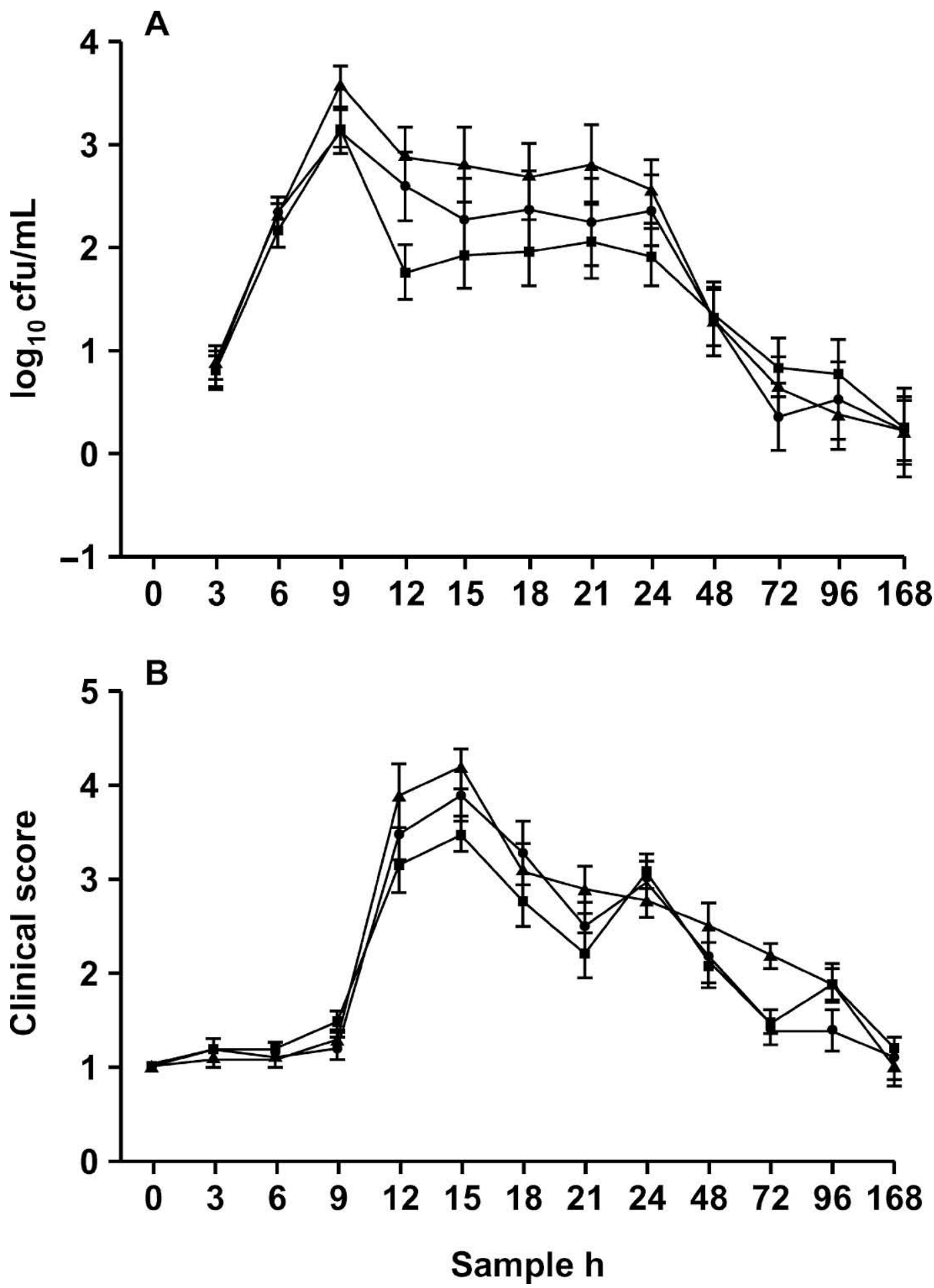

Figure 3. Colony-forming units (A) in milk from challenged quarters and clinical status (B) following intramammary challenge with Escherichia coli 727 at $0 \mathrm{~h}$ for cows vaccinated with Escherichia coli J5 bacterins containing either oil-in-water adjuvant (n = 17; $\mathbf{\square}$ ), watersoluble adjuvant $(\mathrm{n}=13 ; \boldsymbol{\bullet})$, or unvaccinated controls $(\mathrm{n}=15 ; \mathbf{\Delta})$. Dispersion bars represent standard errors of the mean.

among treatment groups (Figure 3). Mean peak bacterial counts in milk (mean $\pm \mathrm{SE} \mathrm{cfu} / \mathrm{mL}$ ) from challenged quarters were greater $(P<0.05)$ in unvaccinated con- trols $(4.6 \pm 0.4)$ compared with those in milk from cows vaccinated with bacterin containing oil-in-water adjuvant $(3.6 \pm 0.4)$. Bacterial counts in milk at $12,15,18$, 
21 , and $24 \mathrm{~h}$ postchallenge were also greater $(P<0.05)$ in unvaccinated cows than cows vaccinated with bacterin containing oil-in-water adjuvant (Figure 3). Other differences in bacterial counts in milk among treatment comparisons were not significant $(P<0.05)$.

Clinical score was greater for unvaccinated controls than for cows vaccinated with bacterin containing oilin-water adjuvant at 21 and $72 \mathrm{~h}$ postchallenge $(P<$ 0.05 ; Figure 3). Clinical score was greater for unvaccinated controls than for cows vaccinated with bacterin containing water-soluble adjuvant at $72 \mathrm{~h}$ postchallenge only $(P<0.05)$. Corresponding to the decreased clinical score in vaccinated cows, duration of clinical signs and duration of IMI were decreased in the vaccinated cows. Geometric mean duration of clinical signs (range 0 to $156 \mathrm{~h}$ ) were $15.8,15.1$, and $29.5 \mathrm{~h}$ for cows vaccinated with bacterin containing water-soluble adjuvant, oil-in-water adjuvant, and unvaccinated controls, respectively. Geometric mean (range 0 to $165 \mathrm{~h}$ ) duration of IMI were $56.2 \mathrm{~h}$ for cows immunized with bacterin containing water-soluble adjuvant, $46.7 \mathrm{~h}$ for cows immunized with bacterin containing water-in-oil adjuvant, and $85.1 \mathrm{~h}$ for unvaccinated controls.

Rectal temperature and SCC of milk from challenged quarters were similar among treatments (Figure 4). Rectal temperature was greater for unvaccinated controls than for vaccinated cows $12 \mathrm{~h}$ postchallenge $(P<$ 0.05). Milk SCC were greater for unvaccinated controls than for vaccinated cows $15 \mathrm{~h}$ postchallenge $(P<0.05)$. Temperature responses and SCC did not differ between cows immunized using different adjuvants $(P>0.05)$.

\section{Relationships Among Injection Site and Clinical Responses}

Injection site reactions greater than $1 \mathrm{~cm}^{2}$ and less than $1 \mathrm{~cm}^{2}$ were used as discrete classifications for investigating the relationship between size of injection site reaction and clinical response to intramammary challenge. Four cows immunized with bacterin containing water-soluble adjuvant had injection site reactions resulting in an area of inflammation greater than $1 \mathrm{~cm}^{2}$ during the $4 \mathrm{~d}$ following primary immunization. Nine cows immunized with bacterin containing watersoluble adjuvant had injection site reactions resulting in an area of inflammation less than $1 \mathrm{~cm}^{2}$ during the 4 $\mathrm{d}$ following primary immunization. Cows with primary injection site reactions greater than $1 \mathrm{~cm}^{2}$ had significantly lower peak bacterial counts $(P<0.05)$ and rectal temperatures $(P<0.08)$ following challenge than did cows with primary injection sites less than $1 \mathrm{~cm}^{2}$ (Figure 5). Peak bacterial counts and rectal temperatures following challenge were similar between cows immunized with bacterin containing water-soluble adjuvant having primary injection site reactions less than $1 \mathrm{~cm}^{2}$ and those of unvaccinated controls.

Nine cows immunized with bacterin containing oilin-water adjuvant had injection site reactions resulting in an area of inflammation greater than $1 \mathrm{~cm}^{2}$ during the $4 \mathrm{~d}$ following primary immunization. Eight cows immunized with bacterin containing oil-in-water soluble adjuvant had injection site reactions resulting in an area of inflammation less than $1 \mathrm{~cm}^{2}$ during the $4 \mathrm{~d}$ following primary immunization. Peak bacterial counts and rectal temperatures did not differ between cows immunized with oil-in-water adjuvant having primary injection site reactions of either greater than 1 $\mathrm{cm}^{2}$ or those with injection site reactions less than 1 $\mathrm{cm}^{2}$ (Figure 6).

Peak bacterial counts and rectal temperatures following challenge were not associated with injection site reactions following the booster injections $42 \mathrm{~d}$ after drying off for cows immunized with water-soluble or oilin-water adjuvants.

\section{DISCUSSION}

The use of $E$. coli J5 bacterin containing an oil-inwater adjuvant was efficacious compared with unvaccinated controls in reducing bacterial counts in milk the $24 \mathrm{~h}$ after challenge. The use of the $E$. coli J5 bacterin containing water-soluble adjuvant did not result in substantial differences compared with unvaccinated controls. The superiority of oil-in-water adjuvants over water-soluble adjuvants has been previously demonstrated using a variety of food and laboratory animals immunized with different antigens (reviewed by Dalsgaard, 1987). The differences among experimental groups in the current trial reflect those observed in earlier experimental challenge trials of cows immunized with $E$. coli J5 bacterin containing water-in-oil adjuvants (Hogan et al., 1992b, 1995). Cows immunized with $E$. coli J5 containing oil-in-water adjuvant had lower peak bacterial counts and reduced severity and duration of clinical signs compared with unvaccinated controls in the current trial. Clinical signs after challenge did not differ between cows vaccinated with the $E$. coli J5 bacterin containing water-soluble adjuvant and unvaccinated controls.

Cows vaccinated with $E$. coli J5 containing oil-inwater adjuvant had more severe injection site reactions than cows vaccinated with $E$. coli J5 containing watersoluble adjuvant. A local reaction caused by the oil portion of adjuvants is often credited for inducing the migration of antigen-presenting cells and formation of a depot for sustained release of antigen (Morein et al., 1996). Unfortunately, these local reactions can occasionally develop into sterile abscesses or granulomas 

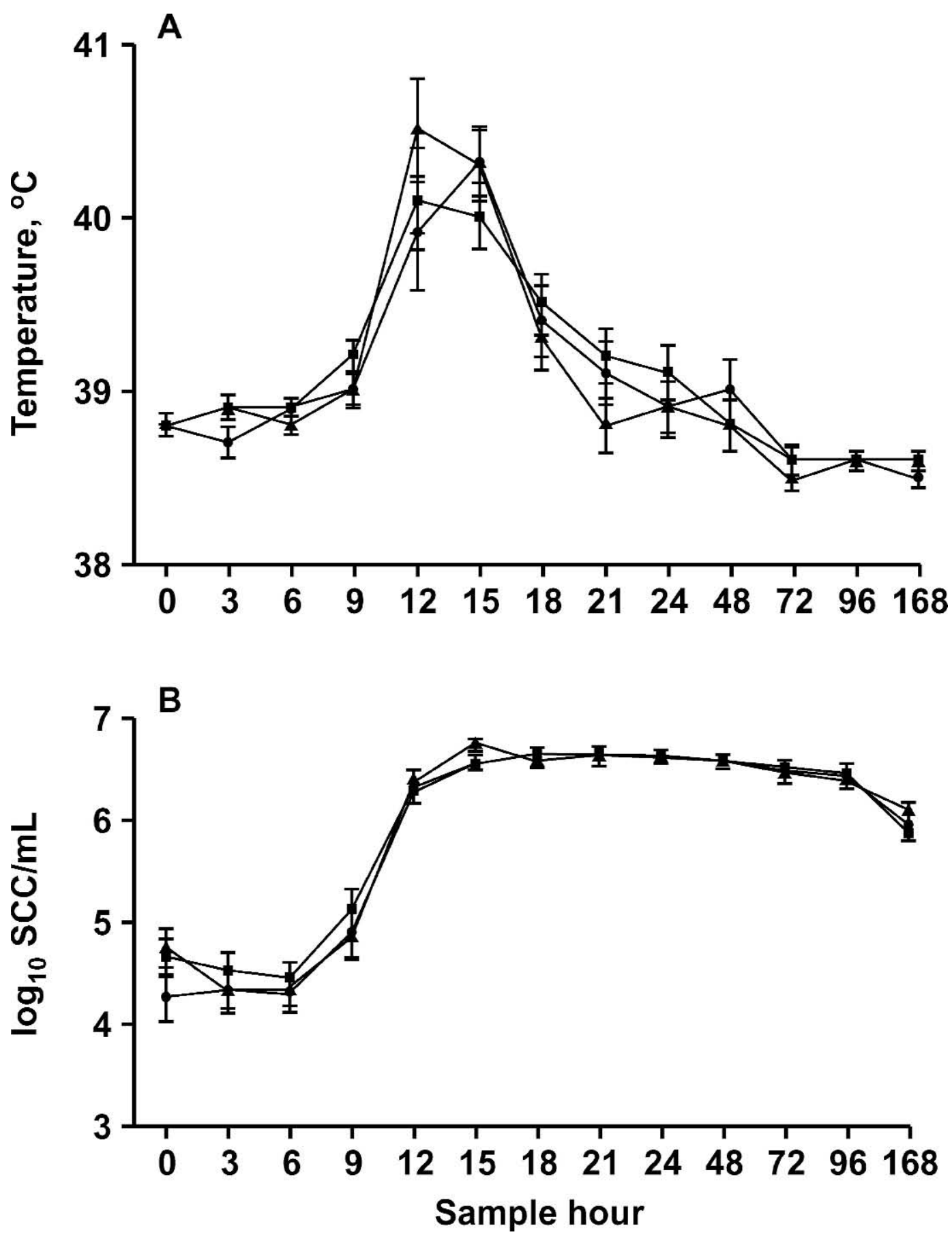

Figure 4. Rectal temperature (A) and SCC for milk from challenged quarters (B) following intramammary challenge with Escherichia coli 727 at $0 \mathrm{~h}$ for cows vaccinated with Escherichia coli J5 bacterins containing either oil-in-water adjuvant (n = 17; $\mathbf{0})$, water-soluble adjuvant $(n=13 ; \bullet)$, or unvaccinated controls $(n=15 ; \mathbf{\Delta})$. Dispersion bars represent standard errors of the mean.

(Spickler and Roth, 2003). Less severe reactions still pose a potential problem to carcass quality, animal discomfort, and aesthetics. No relationship was observed between efficacy and injection site reaction within the oil-in-water adjuvant group. However, the presence of a swollen area greater than $1 \mathrm{~cm}^{2}$ at the site of the primary immunization was associated with greater efficacy of the bacterin in the group immunized with the water-soluble adjuvant. Although only $30 \%$ of these animals had an injection site reaction greater than $1 \mathrm{~cm}^{2}$, 

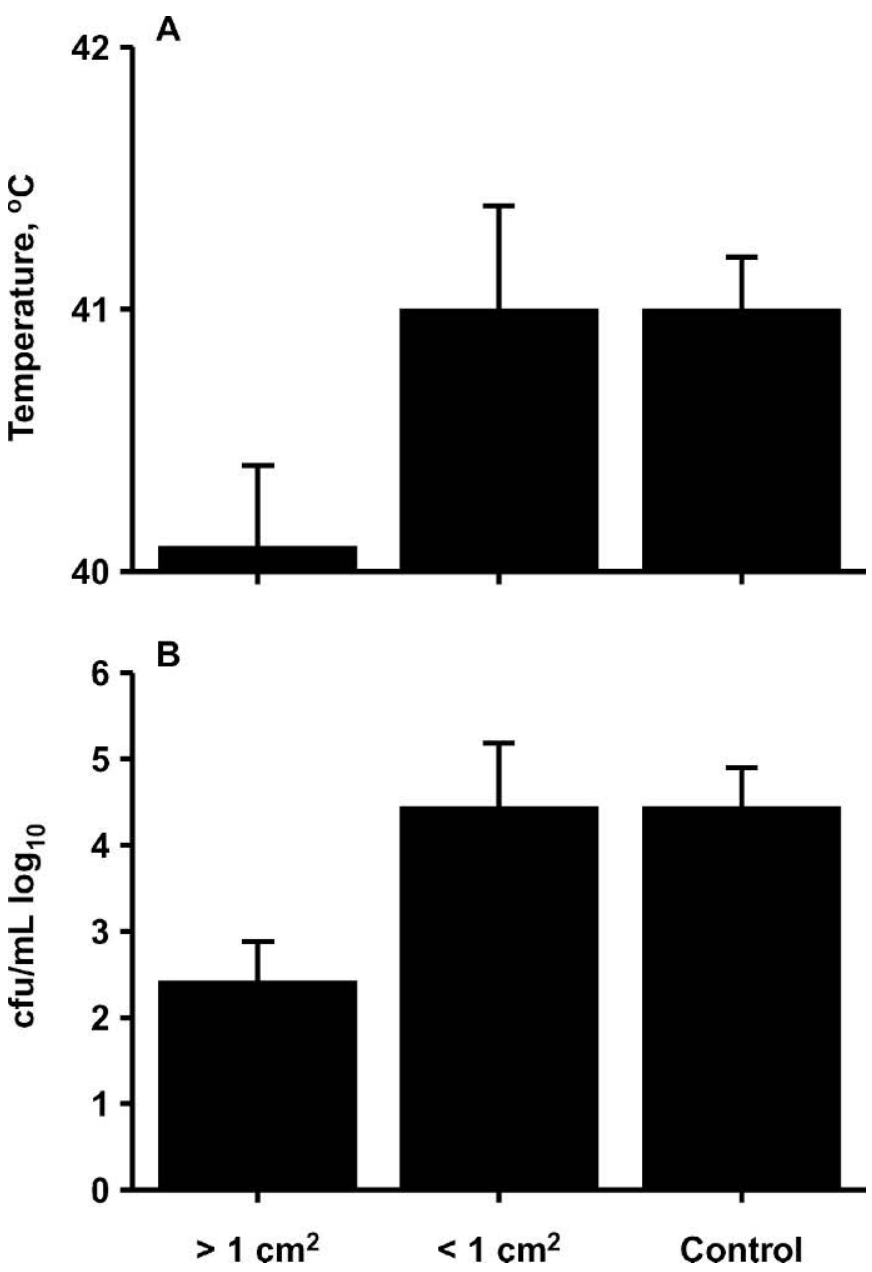

Figure 5. Peak rectal temperature (A) and peak colony formingunits in challenged quarters (B) following intramammary challenge in cows immunized with Escherichia coli J5 bacterin containing water-soluble adjuvant having primary injection site reactions $>1 \mathrm{~cm}^{2}$ $(\mathrm{n}=4)$, cows with primary injection sites $<1 \mathrm{~cm}^{2}(\mathrm{n}=9)$, and unvaccinated controls $(\mathrm{n}=15)$. Dispersion bars represent standard errors of the mean.

the clinical responses following experimental intramammary challenge of these cows were similar to the clinical responses of animals immunized with the oilin-water adjuvant. Cows immunized with the watersoluble adjuvant that did not have injection site reactions after the primary immunization responded to experimental challenge similarly to the unvaccinated controls. These results allude to the claims of previous reports that injection site reactions may be critical to the success of bacterins used in food animals (Morein et al., 1996). The mechanism by which inflammation at the injection site, caused by oil adjuvants, facilitates induction of acquired immunity is poorly defined (Singh and O'Hagan, 1999). Likewise, the cause and mechanism of reaction sites observed in cows immunized with
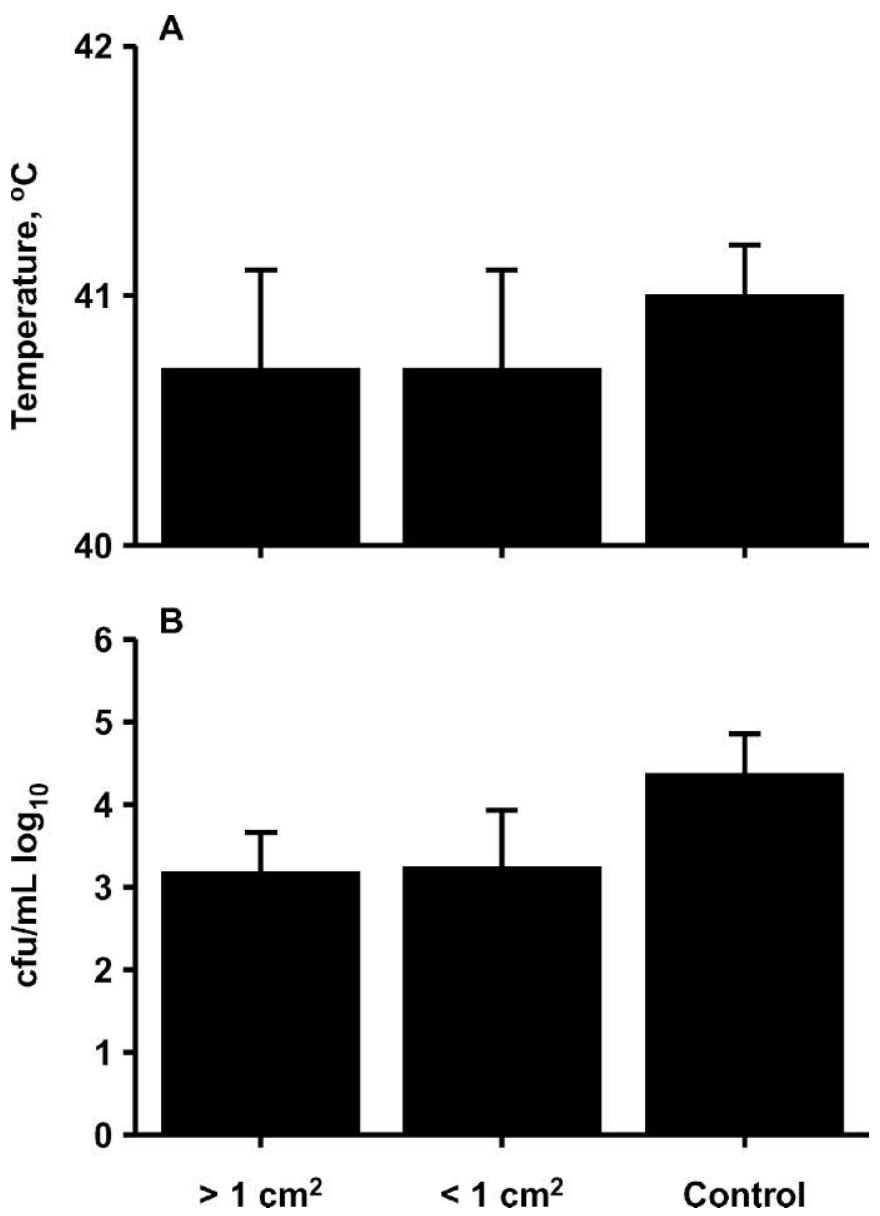

Figure 6. Peak rectal temperature (A) and peak colony formingunits in challenged quarters (B) following intramammary challenge in cows immunized with Escherichia coli J5 bacterin containing oilin-water adjuvant having primary injection site reactions $>1 \mathrm{~cm}^{2}(\mathrm{n}=$ 9 ), cows with primary injection sites $<1 \mathrm{~cm}^{2}(\mathrm{n}=8)$, and unvaccinated controls $(n=15)$. Dispersion bars represent standard errors of the mean.

the water-soluble adjuvant in the present trial are conjecture. Individual cows may have been more sensitive to components of the bacterin or experienced greater trauma during injection compared with study cohorts. Regardless of the cause or mechanism, the formation of a reaction site did appear to be related to conferring protection against bacterial challenge.

\section{CONCLUSIONS}

The use of an oil-in-water adjuvant increased the efficacy of an $E$. coli J5 bacterin over the use of a watersoluble adjuvant. However, the use of the oil-in-water adjuvant also increased the frequency of injection site reactions compared with the water-soluble adjuvant. An injection site reaction area of greater than $1 \mathrm{~cm}^{2}$ was positively associated with efficacy in cows vacci- 
nated with the bacterin containing water-soluble adjuvant.

\section{REFERENCES}

Burton, J. L., A. Chaiyotwittayakun, K. L. Smith, R. Darch, and R. J. Erskine. 2002. Novel applications for coliform mastitis programs. Pages 89-110 in Proc. Natl. Mastitis Counc. Annu. Mtg. Orlando, FL. Natl. Mastitis Counc., Inc, Madison, WI.

Dalsgaard, K. 1987. Adjuvants. Vet. Immun. Immunopath. $17: 145-152$

Gonzales, R. N., J. S. Cullor, D. E. Jasper, T. B. Farver, R. B. Bushnell, and M. N. Oliver. 1983. Prevention of clinical coliform mastitis in dairy cows by a mutant Escherichia coli vaccine. Can. J. Vet. Res. 53:301-305.

Hogan, J. S., K. L. Smith, D. A. Todhunter, and P. S. Schoenberger. 1992a. Field trial to determine efficacy of an Escherichia coli J5 mastitis vaccine. J. Dairy Sci. 75:78-84.

Hogan, J. S., W. P. Weiss, K. L. Smith, D. A. Todhunter, P. S. Schoenberger, and L. M. Sordillo. 1995. Effects of an Escherichia coli J5 vaccine on mild clinical coliform mastitis. J. Dairy Sci. 78:285-290.

Hogan, J. S., W. P. Weiss, D. A. Todhunter, K. L. Smith, and P. S. Schoenberger. 1992b. Efficacy of an Escherichia coli J5 vaccine in an experimental challenge trial. J. Dairy Sci. 75:415-422.

Morein, B., M. Villacres-Eriksson, A. Sjolander, and K. L. Bengtsson. 1996. Novel adjuvants and vaccine delivery systems. Vet. Immunol. Immunopath. 54:373-384.
National Mastitis Council. 1999. Laboratory Handbook on Bovine Mastitis. National Mastitis Council, Inc., Madison, WI.

Ramon, G. 1924. Sur la toxine st sur l'anatoxine diptheriques. Ann. Inst. Pasteur 38:1-10

SAS Institute. 1999. SAS User's Guide. Statistics. SAS Inst. Inc. Cary, NC.

Singh, M., and D. O'Hagan. 1999. Advances in vaccine adjuvants. Nat. Biotechnol. 17:1075-1081.

Smith, J. L., J. S. Hogan, and K. L. Smith. 1999. Efficacy of intramammary immunization with an Escherichia coli J5 bacterin. J. Dairy Sci. 82:2582-2588.

Spickler, A. R., and J. A. Roth. 2003. Adjuvants in veterinary vaccines: Modes of action and adverse effects. J. Vet. Intern. Med. $17: 273-281$.

Takemura, K., J. S. Hogan, and K. L. Smith. 2002. Efficacy of immunization with ferric citrate receptor FecA from Escherichia coli on induced coliform mastitis. J. Dairy Sci. 85:774-781.

Todhunter, D. A., K. L. Smith, and J. S. Hogan. 1991. Intramammary challenge with Escherichia coli following immunization with a curli-producing Escherichia coli. J. Dairy Sci. 74:819-825.

Tomita, G. M., S. C. Nickerson, W. E. Owens, and B. Wren. 1998 Influence of route of vaccine administration against experimental intramammary infection caused by Escherichia coli. J. Dairy Sci. 81:2159-2194.

Tomita, G. M., C. H. Ray, S. C. Nickerson, W. E. Owens, and G. F. Gallo. 2000. A comparison of two commercially available Escherichia coli $\mathrm{J} 5$ vaccines against $E$. coli intramammary challenge. J. Dairy Sci. 83:2276-2281.

Tyler, J. W., J. S. Cullor, S. J. Spier, and B. P. Smith. 1990. Immunity targeting common core antigens of Gram-negative bacteria. J. Vet. Intern. Med. 4:17-25. 